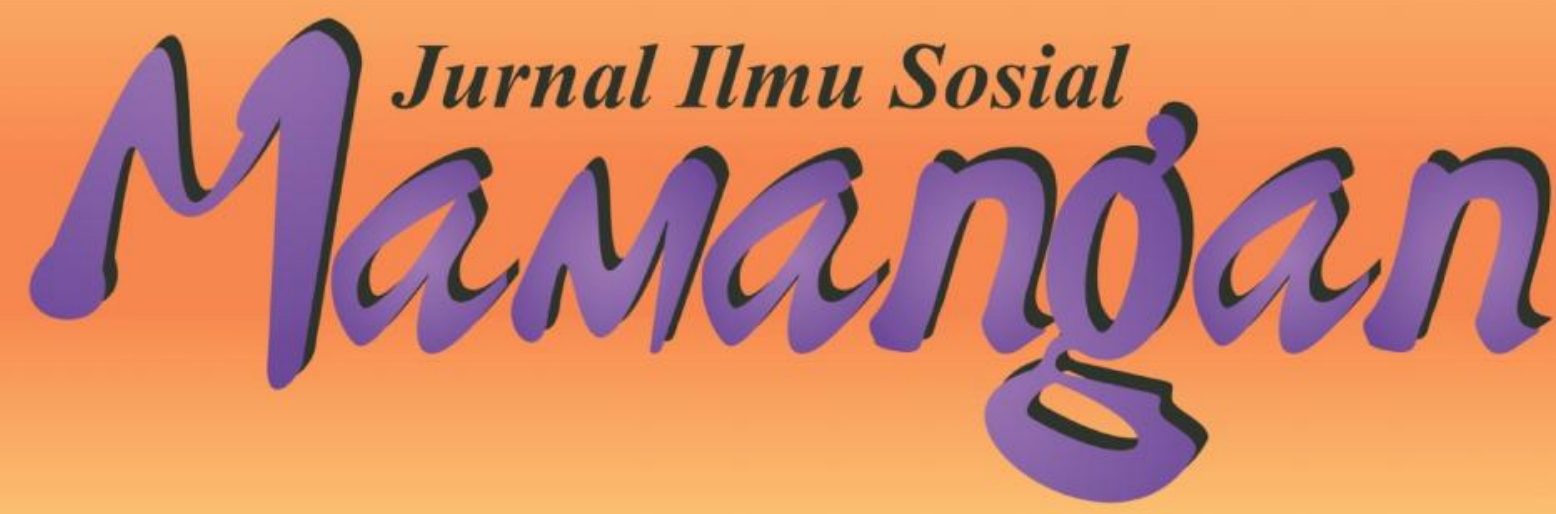

Kehidupan Sosial Ekonomi Petani Nilam Di Desa Taikako, Kec. Sikakap, Kab. Kepulauan Mentawai

Yanti Murni, Ansofino \& Meldawati

Dampak Sosial Konflik Kinali 1999-2010

Welly Ibrahim, Ansofino \& Ahmad Nurul Huda

Pasang Surut Sosial Ekonomi Petani Cengkeh Di Nagari Koto Anau, Kec. Lembang Jaya, Kab. Solok 1960-2011

Yosefrizal, Sabar \& Witrianto

Perubahan Sosial Ekonomi Masyarakat Pasca Pengembangan Wisata Bahari Di Kepulauan Sikakap, Kabupaten Mentawai

Ismi Andriyani, Etmi Hardi \& Liza Husnita

Persepsi Masyarakat Petani Kelapa Terhadap Pendidikan Tinggi Anak Di Kecamatan Siberut Barat, Kabupaten Kepulauan Mentawai

A. Tisnawati Tapondhadhai, Ansofino \& Ranti Nazmi

Kecendrungan Masyarakat Membeli Lahan Sengketa Di Kecamatan VII Koto, Kabupaten Tebo, Jambi

Esri Eni Dewi Mukti, Slamet Rianto \& Dasrizal 


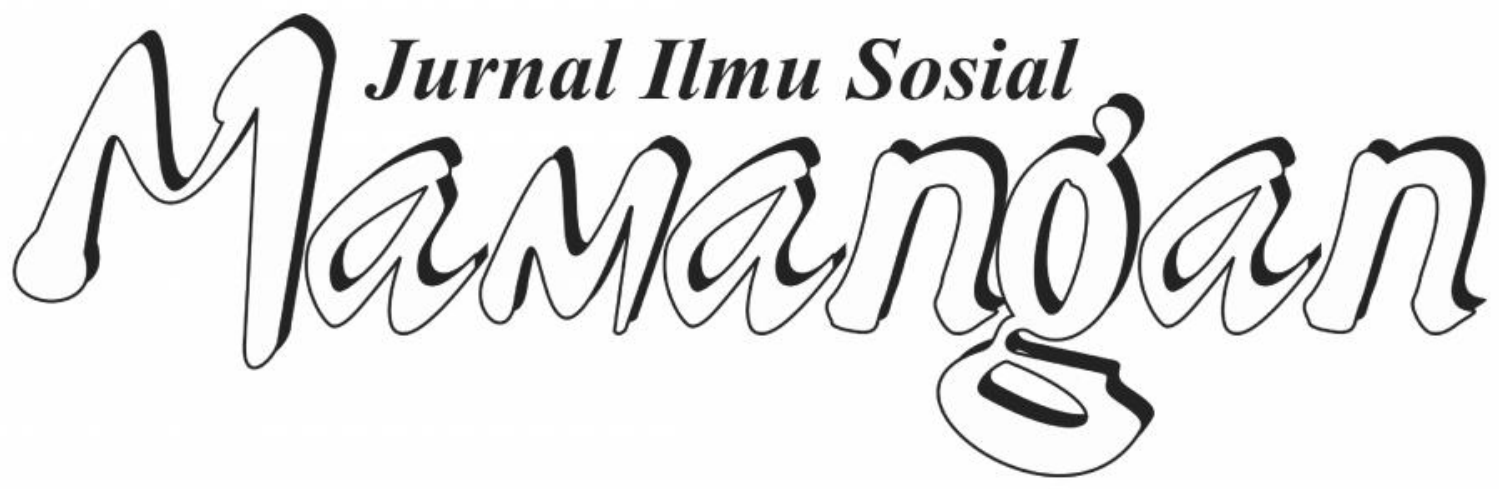




\section{Mitra Bestari}

Prof. Dr. Afrizal, MA. (FISIP, Unand Padang)

Dr. A. Latief Wiyata, M. Si. (Universitas Jember, Jember)

Prof. Dr. Badaruddin, M. Si. (FISIP, USU Medan)

Dr. Fikarwin Zuska, M. Si. (FISIP, USU Medan)

Nurus Shalihin, M. Si., Ph.D. (Fak. Ushuluddin IAIN Imam Bonjol Padang)

Dr. Semiarto A. Purwanto, M. Si. (FISIP, UI Jakarta)

Dr. Wahyu Wibowo, M. Si. (Universitas Nasional, Jakarta)

\section{Dewan Redaksi}

Dr. Zusmelia, M. Si.

Dr. Maihasni, M. Si.

Adiyalmon, S. Ag., M. Pd.

Firdaus, S. Sos., M. Si.

\section{Pemimpin Redaksi}

Firdaus, S. Sos., M. Si.

\section{Anggota Redaksi}

Dian Kurnia Anggreta, S. Sos., M. Si.

Rinel Fitlayeni, S. Sos., MA.

Surya Prahara, SH.

ISSN: 2301-8496

\section{Alamat Redaksi:}

Laboratorium Program Studi Pendidikan Sosiologi, STKIP PGRI Padang

Jl. Gunung Pangilun, Padang

Email: redaksimamangan@yahoo.com

Penerbit :

Program Studi Pendidikan Sosiologi, STKIP PGRI Padang

\section{Contac person :}

Firdaus (Hp. 085263881221/Email : daus gila@yahoo.com) 


\section{DAFTAR ISI}

Kehidupan Sosial Ekonomi Petani Nilam Di Desa Taikako, Kec. Sikakap, Kab. Kepulauan Mentawai

Yanti Murni, Ansofino \& Meldawati.

$60-72$

Dampak Sosial Konflik Kinali 1999-2010

Welly Ibrahim, Ansofino \& Ahmad Nurul Huda

Pasang Surut Sosial Ekonomi Petani Cengkeh Di Nagari Koto Anau, kec. Lembang Jaya, Kab. Solok 1960-2011

Yosefrizal, Sabar, Witrianto

Perubahan Sosial Ekonomi Masyarakat Pasca Pengembangan Wisata Bahari Di Kepulauan Sikakap, Kabupaten Mentawai

Persepsi Masyarakat Petani Kelapa Terhadap Pendidikan Tinggi Anak Di Kecamatan Siberut Barat, Kabupaten Kepulauan Mentawai

A. Tisnawati Tapondhadhai, Ansofino \& Ranti Nazmi.

Kecendrungan Masyarakat Membeli Lahan Sengketa Di Kecamatan VII Koto, Kabupaten Tebo, Jambi 


\title{
KEHIDUPAN SOSIAL EKONOMI PETANI NILAM DI DESA TAIKAKO, KEC. SIKAKAP, KAB. KEPULAUAN MENTAWAI
}

\author{
Yanti Murni, Ansofino \& Meldawati \\ Sekolah Tinggi Keguruan dan Ilmu Pendidikan (STKIP) PGRI Sumatera Barat
}

\begin{abstract}
Desa Taikako is a village form three villages in Kecamatan Sikakap, Kabupten Kepulauan Mentawai. Most of the population is a traditional farmer with kinds of commodities such as coconut, clove, banana, taro and sago. Since 1960 when patchouli is popular in farmer and significance prices in 1997 was improve the economy of farmers. This article describe the growth of patchouli cultivation, socio-economic situation of farmers in Taikako during 1997-2010. Result is the patchouli cultivation well developed in terms of cultivation and plant area. These developments affected the patchouli price. The development of cultivation of patchouli effected to social and economic life of farmers in the period 1997-2010.
\end{abstract}

Keywords : Socio-Economic, Patchouli Farmer, Patchouli Cultivation

\begin{abstract}
ABSTRAK
Desa Taikako merupakan salah satu desa dari tiga desa yang berada di Kecamatan Sikakap, Kab. Kepulauan mentawai. Sebagian besar penduduknya adalah petani tradisional dengan jenis komoditi seperti kelapa, cengkeh, pisang, keladi, sagu. Masuknya tanaman nilam pada tahun 1960-an dan mengalami kenikan harga yang signifikan pada tahun 1997 telah meningkatkan ekonomi petani. Artikel ini akan menjelaskan perkembangan usaha budidaya tanaman nilam, keadaan sosial ekonomi petani nilam di Desa Taikako selama periode 1997-2010. Hasil penelitian menunjukkan bahwa usaha budidaya tanaman nilam di Desa Taikako mengalami perkembangan dengan baik dalam hal budidaya dan luas tanaman yang dikelola. Perkembangan tersebut dipengaruhi oleh nilai jual minyak nilam di pasaran. Perkembangan budidaya tanaman nilam berpengaruh positif terhadap kehidupan sosial ekonomi petani dalam periode 19972010 .
\end{abstract}

\section{Kata Kunci: Sosial Ekonomi, Petani Nilam, Budidaya Nilam}

\section{PENDAHULUAN}

Kabupaten Kepulauan Mentawai merupakan kabupaten yang dimekarkan melalui undang-undang No. 49 tahun 1999. Sebelumnya Mentawai masuk dalam wilayah pemerintahan kabupaten Padang Pariaman, Propinsi Sumatera Barat. Kepulauan mentawai terdiri dari empat pulau besar yang dihuni oleh penduduk, yakni pulau Pagai Selatan, Pagai Utara,
Sipora Dan Siberut. Sejak tahun 2008 kabupaten Kepulauan Mentawai dibagi menjadi 10 kecamatan dan 43 desa, yakni Kecamatan Siberut Barat, Kecamatan Siberut Utara, Kecamatan Siberut Tengah, Kecamatan Siberut Selatan, Kecamatan Siberut Barat Daya, Kecamatan Sipora Utara, Kecamatan Sipora Selatan, Kecamatan Pagai Utara, Kecamatan Sikakap dan Kecamatan Pagai Selatan. 
Kehidupan penduduk masyarakat Kepulauan Mentawai pada umumnya adalah petani dengan jumlah mencapai 82,24 \% dari total jumlah penduduk. Pertanian yang dimiliki masyarkat masih tradisional. Adapun jenis tanaman yang mereka usahakan adalah jenis tanaman untuk memenuhi kebutuhan sehari-hari seperti pisang, keladi, sagu, buah-buahan, kelapa, dan beberapa tanaman komersial lainnya yang telah dikembangkan seperti cengkeh, pala dan coklet, walaupun jumlahnya masih sangat terbatas. Tidak ada perkebunan skala besar di Mentawai walaupun sebelumnya ada rencana pembukaan perkebunan sawit.

Berbagai upaya mereka lakukan untuk mengembangkan ekonomi pertaniannya. Saat masih berada di wilayah pemerintahan kabupaten Padang Pariaman telah disosialisasikan kepada masyarakat untuk menanam tanaman padi, kelapa, cengkeh, pala, dan berbagai tanaman buah-buahn lainnya seperti rambutan, mangga dan jeruk, namun yang banyak dikembangkan masyarkat adalah kelapa, cengkeh, dan tanaman padi. Sejak tahun 1980-an tanaman nilam sudah mulai masuk di Kepulauan Mentawai yang dibawa oleh masyarkat petani dari kepulauan Nias, namun pada saat itu tidak terlalu banyak yang membudidayakannya karena harga di pasaran sangat rendah. Namun sejak tahun 1997 harga minyak nilam mencapai $\mathrm{Rp}$ $350.000 / \mathrm{kg}$ dan bahkan lebih. Berdasarkan nilai akonomi tersebut mayoritas masyarakat Mentawai membuka kebun nilam, tidak terkecuali di Kecamatan Sikakap.

\section{Tabel 1}

Luas Tanaman dan Produksi Tanaman Nilam di Sikakap Tahun 2010.

\begin{tabular}{|c|c|c|c|c|}
\hline No & Desa & $\begin{array}{c}\text { Luas } \\
\text { tanam } \\
\text { (ha) }\end{array}$ & $\begin{array}{c}\text { Produksi } \\
\text { (ton) }\end{array}$ & $\begin{array}{c}\text { Jumlah } \\
\text { petani }\end{array}$ \\
\hline 1 & Taikako & 70 & 5,3 & 712 \\
\hline 2 & Sikakap & 8,4 & 0,5 & 217 \\
\hline 3 & Matobe & 43,5 & 2,3 & 426 \\
\hline & Jumlah & & & \\
\hline
\end{tabular}

Sumber : Statistik Kecamatan Sikakap, 2011.

Data di atas menunjukkan bahwa pada tahun 2010 desa Taikako merupakan desa yang paling luas menanam tanaman nilam yakni mencapai 70 Ha dibanding dua desa lainnya di Sikakap. Desa Taikako merupakan salah satu desa terpencil di dalam wilayah pemerintahn Kecamatan Sikakap. Sebelumnya desa Taikako masuk dalam wilayah Kecamatan Pagai Utara Selatan yang telah dimekarkan menjadi tiga kecamatan pada tahun 2008 yakni kecamatan Pagai Utara, Sikakap dan Pagai Selatan. Desa Taikako terdiri dari 13 dusun yakni dusun Kaute, Pasibuat, Taikako Timur, Taikako Barat, Pumagirat, Matoimimit Jaya, Silaoinam, Taikako Hulu, Bulak Monga, Bosua Girau, Rakrak Joja dan Dusun Muara Taikako. Gambaran wilayah desa Taikako umumnya adalah dataran dan perbukitan dengan ketinggian kurang lebih 0-150 mdpl.

Jumlah penduduk kecamatan Sikakap pada tahun 2010 adalah 9.461 jiwa dengan luas wilayah $552,12 \mathrm{~km}^{2}$. Tanah di desa Taikako hampir seluruhnya cocok untuk ditanami nilam, karena tanah yang masih subur sehingga masyarakat dalam memelihara tanaman nilam tidak menggunakan pupuk dan minyak nilam yang dihasilkan memiliki kualitas yang sangat baik dibandingkan dengan minyak nilam yang dihasilkan daerah lain. Pada tahun 1997 masyarkat desa Taikako mengetahaui harga minyak nilam sangat tinggi di pasaran. Mereka mendapatkan informasi, bahwa tanaman nilam memiliki harga yang cukup baik dan selalu mengalamai kenaikan setiap bulannya, serta pemeliharaanya yang hanya membutuhkan waktu 6 bulan sudah bisa panen, mereka berupaya untuk meningkatkan ekonominya dengan mengembangkan tanaman nilam.

Saat harga nilam mencapai satu juta $/ \mathrm{kg}$, masyarakat berbondong-bondong membuka kebun dan menanam nilam, mencari bibit yang baik dan mencari pengetahuan tentang penanaman, pengolahan nilam yang baik. Selama ini masyarakat hanya melakukan apa kata orang lain dan pengalaman orang lain untuk bertanam, itupun sangat terbatas, namun karena masih suburnya tanah dan masih luasnya tanah di Taikako, petani masih dapat menanam nilam dan menghasilkan minyak secara terus-menerus. Berdasarkan latar belakang yang telah dikemukakan di atas, tulisan ini bertujuan untuk mendeskripsikan perkembangan serta 
keadaan sosial ekonomi petani nilam didesa Taikako kecamatan Sikakap Kabupaten Kepulauan Mentawai selama periode 19972010 dan perkembanagan dan perubahan ekonomi dan sosial petani nilam masyarakat di Desa Taikako Kecamatan Sikakap Kabupaten Kepulauan Mentawai.

Agar tidak terjadi penyimpangan dan untuk mempermudah dalam pemahaman pokok permasalahan tulisan ini dibatasi pada petani di Desa Taikako Kecamatan Sikakap Kabupaten Kepulauan Mentawai. Pembahasan juga dibatas dalam rentang waktu 1997-2010. Pembatasan dilakukan berdasarkan pertimbangan bahwa pada masa itu minyak nilam mengalami kenaikan yang sangat fantastis yang mencapai $\mathrm{Rp}$. $350.000-/ \mathrm{kg}$ dan setiap bulan selalu mengalami kenaikan.

\section{TINJAUAN PUSTAKA}

Penelitian tentang kehidupan sosial ekonomi petani nilam telah banyak dilakukan para peneliti terdahulu, antara lain adalah membahas tentang beberapa alasan yang mempengaruhi petani nilam dalam mengembangkan dan menanam nilam. Penelitian ini menemukan bahwa alasan petani membudidayakan nilam adalah karena pertumbuhanya yang sangat mudah, minyaknya bisa disimpan dan tahan lama, pemasaran yang tidak sulit dan harganya yang tinggi (Surya, 1991). Di Desa IV Koto, Kkinali, masyarakat membudidayakan nilam adalah karena kondisi alam yang cocok, membutuhkan modal yang relatif kcil, ketersediaan tanah yang cukup banyak, dapat dilakukan sebagai tanaman sela, tenaga kerja tidak diperlukan keahlian khusus. Tanaman nilam sudah dianggap sebagai tanaman tradisional, pemasaran sangat mudah, harga yang sangat fluktuatif juga sangat berpengaruh pada pengolah minyak yang dilakukan oleh masyarkat. Selain itu, pada periode 1990 pertanian nilam di Desa IV Koto telah memberi kemakmuran pada petani setempat, walaupun kemakmuran itu tidak bersifat tetap karena tergantung pada keaadan pasar minyak nilam. Dampak dari perkebunan nilam tersebut terlihat pada kehidupan sosial ekonomi petani nilam, terutama pada pendapatan ekonomi rumah tangga sehingga mereka telah bisa membeli barang-barang mewah seperti televisi, radio, VCD dan lain-lain (Triyani, 2004).

Penelitian lainnya di Kinali menemukan bahwa dengan adanya tanaman nilam di nagari Kinali petani lebih banyak memfokuskan kegiatan dan sumber ekonomi petani pada tanaman niilam. Fluktuasi harga nilam yang tidak menentu menjadi permasalahan utama yang dihadapi petani nilam, sehingga sangat mempengaruhi luasan dan produksi nilam yang diperoleh dikenagarian kinali kabupaten pasaman (Wati, 2004). Studistudi tentang pertanian nilam yang sudah banyak diungkap tentang perkembangan kehidupan sosial ekonomi petani. Dampak pada kehidupan sosial ekonomi petani nilam di desa Taikako saat ini belum ada yang mengkajinya. Fakta menunjukan bahwa tanaman nila di desa Taikako di tahun 1997 sampai tahun 2010 telah mejadi sumber ekonomi utama sampai sebagian petani meninggalkan pengelolaan kebun kelapa yang selama ini telah menjadi sumber utama ekonomi mereka.

\section{METODE}

Penelitian ini termasuk dalam penelitian sejarah, untuk mendapatkan data yang relavan dengan permasalahn penelitian, maka digambarkan langkahlangkah penelitian yang pertama heuristik (pengumpulan sumber) dengan data primer dan dengan sekunder, kedua melakukan pengkajian data melalui kritik eksternal dan internal, ketiga interprestasi, keempat historiografi.

\section{PERTUMBUHAN \& PERKEMBANGAN TANAMAN NILAM DI DESA TAIKAKO (1997-2010)}

Didaerah kabupaten kepulauan mentawai khsusnya di Desa Taikako tanaman nilam tidak ada yang mengetahui secara pasti siapa dan kapan masuknya, karena menurut masyarakat bahwa nilam sudah ada sejak dulu dan dikenal oleh masyarakat dengan nama patiggoilok, namun mereka menggunakannya sebagai obat luka dengan cara ditumbuk dan ditempelkan pada daerah yang luka. Tanaman nilam menjadi tanaman komoditi yang diperdagangkan, masyarakat mentawai mengenalnya sejak tahun 1960an melalui bapak Letnan Saminan sebgai 
anggota TNI ( Tentara Nasional Indonesia) angkatan laut yang pada saat itu ditugaskan untuk melaksanakan kegiatan menunggal bakti yang dilaksakan disikakap khususnya di Desa Taikako. Letnan Saminan membawa satu ikat tanaman nilam yang diperkenalkan kepada masyarakat dengan harapan agar masyarakat mentawai yang ada di Sikakap dapat mengembangkan dan membudidayakannya. Pada saat tanaman nilam diperkenalkan pada masyarakat, ternyata jenis tanaman nilam itu sudah ada dengan nama lokal patiggoilok. Pada saat itu diperkenalkan bahwa tanaman tersebut bisa laku dijual, masyarakat terutama petani berupaya mencari bibit nilam yang memiliki kandungan minyak yang lebih baik., karena tanaman nilam yang ada di Mentawai kandungan minyaknya tidak terlalu banyak.

Sebagian besar pada awalnya bibit nilam diperoleh dari pulau Nias, maka penduduk desa Taikako menanam dan mengembangkannya, namun tidak terlalu banyak orang yang menanam karena harganya masih murah. Harga daun kering yang sudah di cincang $\mathrm{Rp} 25$,- per $\mathrm{kg}$, sedangkan minyak yang sudah disuling harganya Rp 10.000-Rp 15.000 per kg.

Di Desa Taikako, tepatnya pada dusun Silaoinam petani yang memulai mengembangkan tanaman nilam adalah Nahason, kemudian diikuti oleh keluarga Maralus, Simanjuntak, Sabam dan sampai menyeluruh di semua penduduk Silaoinan khususnya dan dilingkungan dan di lingkungan Desa Taikako umumnya. Di dusun Taikako hulu yang mengembangkan pertama kalinya adalah Rojar Sababalat dengan mengambil bibit nilamnya dari Nahason di dusun Silaoinan, sedangkan di dusun Muara Taikako pertama kali yang mengembangkan tanaman nilam adalah Tawarik dan menyebar pada seluruh masyarakat Desa Taikako.

Selama sepuluh tahun lebih tanaman nilam telah dikenal masyarakat Desa Taikako, namun hanya sebagian orang saja yang mengembangkan yang mencapai ${ }^{1 / 2}$ ha dalam satu keluarga, pekerjaan tersebut hanya dikelola oleh tenaga keluarga sendiri yakni suami, istri dan anak-anak. Pada umumnya yang mengusahakan tanaman nilam tahun 1980-an hanya sampai 10 kepala keluarga dari 215 kepala keluarga yang ada di Desa Taikako. Masyarakat yang mananam nilam adalah petani yang memiliki motivasi anak-anaknya yang mau sekolah di SMP, SMA, maupun di perguruan tinggi, karena masyarkat tidak meiliki kebun kelapa sebagai pendapatan utama masyarakat di desa Taikako untuk mendapatkan uang, sedangkan kebun cengkeh hanya berbuah sekali dalam dua tahun.

Pada tahun 1990-an harga penjualan minyak nilam mengalami kenaikan menjadi RP 25000- Rp 30.000/ Kg, yang pada awalnya hanya, Rp 10.000-Rp 15.000/ Kg. Naiknya hatga jual minyak nilam, masyarakat desa Taikako, terutama petani berusaha beramai-ramai membuka kebun nilam ada yang ditanam di sela-sela kebun pisang, kebun buah, dan kebun kelapa namun ada juga yang membuka kebun baru dengan membuka pembukaan hutan.

Pada tahun 1998, lebih dari 90\% masyrakat desa Taikako menjadi nilam sebagai tanaman utama. Meskipun tanaman utama masyarkat adalah menanam nilam, tetap masyarakat masih menanam pisang, keladi, dan tanaman muda lainnya yang berfungsi sebagai persediaan kebutuhan sehari-hari dan sebagian dijula dipasar kecamatan Sikakap. Sudah menjadi kebiasaan bagi masyarkat bagi penduduk Mentawai bahwa disetiap kebun selalu ditanamberbagi tanaman lain yang bisa dipergunakan untuk memenuhi kebutuhan sehari-hari.

Semakin membaiknya harga minyak nilam, masyarakatpun semakin banyak membuka kebun termasuk mereka pegawai negeri maupun pedagang. Sudah menjadi kebiaan masyarakat petani dimana ada jenis tanaman yang memiliki harga jula pasaran yang cukup baik, maka masyarakat akan berlomba untuk memperluas kebunnya hal ini pernah terjadi pada tahun 1970-an masuknya tanman cengkeh didaerah Taikako masyarakat mendengarkan harga cengkeh mencapai RP 1000- Rp 2500 tiap KG, bila memiliki $2-3 \mathrm{~kg}$ cengkeh sudah bisa membeli satu emas yang harganya pada saat itu Rp 5.000- Rp 7.500/ emas.

Meluasnya kebun nilam yang dimiliki masyarakat, maka hampir setiap keluarga petani mengupayakan penyulingan sendiri yang dipasang didekat kebun masingmasing hal ini dilakukan karena sumber air 
dan kayu tidak sulit karena sudah tersedia dikebun tersebut maka petani tidak terbebani untuk mebawa daun nilam dan kayu bakar ke kampung karena penyulingan sudah tersedia di setiap kebun nilam petani.

Dengan naiknya harga minyak nilam, petani yang telah lebih dahulu membuka kebun dan menanam nilam, merakalah yang paling beruntung menikmati atas kenaikan harga, beberpa orang petani yang lebuh dulu menikmati harga nilam adalah Nahason, Maralus, Sadar Sababalat, Sabam Beressigep, Rojar Sabalalat, mengetahui harga nilam dari Rp 50.000/ kg mengalami kenaikan RP 350.000 s/d Rp 500.000/kg , masyarakat yang lain terutama petani berlomba membuka kebun baru dengan membuka hutan sebagai lokasi penanaman nilam.

Nahason dan beberapa petani lainnya yang telah memiliki kebun nilam yang luas, menjadi tempat masyarakat untuk mendapatkan bibit, kadang dari desa lain berdatangan untuk mendapatkan bibit nilam, karena banyaknya masyakat yang ingin menanam nilam sehingga petani ada yang berangkat ke pulau Nias untuk mencari bibit, puncaknya pada tahun 1998 harga nilam mengalami kenaikan $\mathrm{Rp}$ $750.000 \mathrm{~s} / \mathrm{d}$ Rp 1.000.000. naiknya harga nilam yang mencapau Rp 750.000- 1 Juta, negara sednag dalam posisi yang tidak stabil hal tersebut terjadinya berbagai gejolak reformasi diberbgai daerah, dengan kondisi itu umumnya petani di kepulauan Mentawai memperoleh keuntungan yang sangat besar sehingga petani dapat mengembangkan dan memperluas kebun nilamnya.

Harga nilam dari tahun 1997 sampai dengan tahun 2000, berkisar Rp 500.000 $\mathrm{s} / \mathrm{d} \mathrm{Rp}$ 1.200.000, per $\mathrm{kg}$, harga nilam ternyata tidak stabil tergantung permintaan pasar dan permainan para pedagang. Para pedagang besar kadang meraka ke kampung-kampung mencarinnilam, kesempatan ini sangat baik bagi petani. Banyaknya pedagang yang mencari minyak nilam, membuat minyak nilam sulit dicari karena petani tidak dapat memaksa tanaman nilam agar dipanen lebih cepat, karena petani harus menunggu waktu enam bulan untuk panen perdana, setelah panen pertama menunggu lagi selama tuga bulan untuk panen berikutnya, itupun bila tanahnya

masih

subur.

Di sebagian tempat pemanenan nilam hanya dapat melakukan dua kali. Batang tanaman nilam tang masih ada terkadang tidak lagi mengalami pertumbuhan dengan baik bahkan ada terkadang tidak lagi mengalami pertumbuhan dengan baik bahkan ada ayng mengalami layu, daun kering, dan bahkan ada ayng mati. Dengan kondisi tersebut petani melakukan pencabutan tanaman yang sakit tersebut dan menanam bibit baru dan terkadang lebih banyak membuka kebun baru.

Perkembangan luas kebun nilam dari tahun 1995 sampai dengan tahun 2010 dapat dilihat pada tabel 7 di bawah ini :

\section{Tabel 7.}

Luas dan Produksi Minyak Nilam Desa Taikako Kecamatan Sikakap Tahun 1995-2010

\begin{tabular}{|c|c|c|}
\hline Tahun & $\begin{array}{c}\text { Luas Lahan } \\
\text { (ha) }\end{array}$ & $\begin{array}{c}\text { Produksi } \\
(\mathrm{kg})\end{array}$ \\
\hline 1995 & 5 & 330 \\
\hline 1996 & 17 & 845 \\
\hline 1997 & 89 & 6070 \\
\hline 1998 & 148 & 11457 \\
\hline 1999 & 165 & 12383 \\
\hline 2000 & 165 & 12120 \\
\hline 2001 & 155 & 11684 \\
\hline 2002 & 140 & 10327 \\
\hline 2003 & 137 & 10268 \\
\hline 2004 & 120 & 8700 \\
\hline 2005 & 116 & 8538 \\
\hline 2006 & 110 & 8125 \\
\hline 2007 & 97 & 7212 \\
\hline 2008 & 84 & 6370 \\
\hline 2009 & 79 & 5950 \\
\hline 2010 & 70 & 5367 \\
\hline
\end{tabular}

Sumber : Data Statistik Desa Taikako, dan Mentawai Dalam angka 2011.

Dari tabel 7 diatas dapat dilihat bahwa tanaman nilam mengalami perluasan dari tahun ketahun yang cukup menyolok, terutama antara tahun 1995 samapi dengan tahun 2000 dengan luas lahan nilam yang ditanam mencapai 165 hektar sedangkan dari tahun 2001 sampai dengan tahun 2010 secara umum terjadi penurunan, hal tersebut sangat terkait dengan terjadinya penurunan harga minyak nilam dipasaran. Terjadinya perkembangan luas kebun nilam dari tahun 1995 sampai dengan tahun 2000 
ini disebabkan kenaikan harga nilam dipasaran dari Rp. 15.000 per kg naik lagi menjadi Rp 75.000,- dan hampir setiap bulan terjadi kenaikan mencapai Rp,1.200.000,-, melihat perkembangan kenaikan harga membuat masyarakat terutama petani membuat kebun nilam.

Pada tahun 2001 sampai dengan 2010 terjadi stagnan perluasan kebun nilam bahkan lebih cenderung terjadi penurunan ini disebabkan beberapa faktor diantaranya adalah (1) terjadinya penurunan harga minyak nilam dipasaran, (2) sebahagian petani tidak lagi memiliki tanah untuk membuka kebun baru, (3) kebun lama sudah tidak subur sehingga tetap dipelihara dan ditanam hasilnya tidak akan maksimal, (4) bila dibuka kebun baru lokasinya sudah sangat jauh dari kampung dan jauh dari sumber air untuk melakukan penyulingan,(5) tahun 2005 tanaman cokelat mulai dikembangkan di Mentawai sehingga petani di desa Taikako ikut mengembangkan yang ditanam dilahan bekas kebun nilam.

Tanaman nilam di Taikako masih bisa berprodusi sampai pada umur 3 tahun pada tanah yang subur dan pada kebun baru sedangkan bila ditanam disela tanaman pisang dan kebun kelapa hanya bisa berproduksi sampai umur 2 tahun, setelah dilakukan pembukaan kebun baru dan dengan peremajaan, hal ini terjadi karena masyarkat petani nilam tidak melakukan pemupukan. Pembukaan kebun baru membutuhkan waktu yang cukup lama, sementara bila dilakukan peremajaan tanaman umurnya lebih pendek hanya dua kali panen sudah tidak produktif lagi. Dengan demikian petani banyak yang tidak memelihara kebun nilam namun di isi oleh tanaman lain terutama pisang dan keladi.

Masuknya tanaman coklat, tidak semua petani nilam mengalihkan kebun nilamnya ke kebun coklat, seperti Sadar seorang petani nilam di desa Taikako menyatakan,." biar pun susah mengolah nilam tetapi lebih banyak untungnya dari pada tanaman coklat, maka sampai sekarang saya masih tidak berhenti menanam nilam, karena dari hasil nilamlah memperoleh sumber ekonomi yang lebih baik". Sejak tahun 2005 masyarakat kembali melakukan pembersihan kebun nulam yang sudah diterlantarkan, namun tidak mengembangkan tanaman nilam lagi tetapi mengisi kebun tersebut dengan tanaman coklat, tanaman nilam yang masih tersisa tetap dibiarkan untuk tumbuh. Tidak semua petani yang menanam kebun coklat sebagian kembali mengolah kebun kelapa yang umumnya ada dipulau-pulau kecil yang jauh dari desa Taikako, sebagaian lagi masyarakat menjadi nelayan. Petani yang tidak memiliki kebun kelapa tetap bertahan untuk memelihara dan mengembangkan kebun nilam. Petani yang memiliki tanah luas dengan leluasa melakukan rotasi penanaman dari tempat yang satu tempat yang lainya. Hal lain yang membuat petani nilam bertahan memlihara dan mengembangkan tanaman nilam adalah petani yang memiliki anak sekolah di SMP, SMA, maupun perguruan Tinggi.

Penambahan luas kebun nilam petani sangat dipengaruhi oleh perkembangan harga dipasaran, makin tinggi harga minya nilam, maka semakin luas kebun nilam yang ditanam dan dikembangkan oleh petani, hal ini sudah menjadi kebiasaan petani dipedesaan, bila mendapatkan informasi ada jenis komoditi pertanian yang memiliki nilai jual tinggi, maka petani secara serentak akan mengembangkan tanaman tersebut, seperti yang terjadi pada tanaman cengkeh pada tahun 1976. Berikut adalah daftar perkembangan harga minyak nilam di Desa Taikako Kecamatan Sikakap dari tahun 1995-2010.

Tabel 8.

Harga Minyak Nilam di Desa Taikako Kecamatan Sikakap Tahun 1995-2010.

\begin{tabular}{|l|l|l|}
\hline No & Tahun & Harga / kg (Rp) \\
\hline 1 & 1995 & $15.000 \mathrm{~s} / \mathrm{d} 30.000$ \\
\hline 2 & 1996 & $35.000 \mathrm{~s} / \mathrm{d} 50.000$ \\
\hline 3 & 1997 & $75.000 \mathrm{~s} / \mathrm{d} 350.000$ \\
\hline 4 & 1998 & $250.000 \mathrm{~s} / \mathrm{d} 500.000$ \\
\hline 5 & 1999 & $500.000 \mathrm{~s} / \mathrm{d} 1.200 .000$ \\
\hline 6 & 2000 & $700.000 \mathrm{~s} / \mathrm{d} 850.000$ \\
\hline 7 & 2001 & $300.000 \mathrm{~s} / \mathrm{d} 500.000$ \\
\hline 8 & 2002 & $200.000 \mathrm{~s} / \mathrm{d} 350.000$ \\
\hline 9 & 2003 & $150.000 \mathrm{~s} / \mathrm{d} 300.000$ \\
\hline 10 & 2004 & $200.000 \mathrm{~s} / \mathrm{d} 350.000$ \\
\hline 11 & 2005 & $200.000 \mathrm{~s} / \mathrm{d} 350.000$ \\
\hline 12 & 2006 & $350.000 \mathrm{~s} / \mathrm{d} 450.000$ \\
\hline 13 & 2007 & $200.000 \mathrm{~s} / \mathrm{d} 350.000$ \\
\hline 14 & 2008 & $350.000 \mathrm{~s} / \mathrm{d} 400.000$ \\
\hline 15 & 2009 & $350.000 \mathrm{~s} / \mathrm{d} 400.000$ \\
\hline
\end{tabular}


\begin{tabular}{l|l|l}
16 & 2010 & $250.000 \mathrm{~s} / \mathrm{d} 350.000$
\end{tabular}

Sumber : Kecamatan Sikakap Dalam Angka Tahun 2011 dan Data Primer.

Tingginya harga minyak nilam pada masa itu antara lain merupakan dampak dari krisis ekonomi yang terjadi di Indonesia. Krisis ekonomi yang terjadi akhir tahun 1997, dan dampaknya baru dapat dilihat jelas pada tahun 1998. Keadaan tersebut juga mempengaruhi penghasilan minyak nilam petani. Minyak nilam yang diperdagangkan di dunia Internasional dinilai berdasarkan dollar. Pada tahun 1998 nilai tukar dolar terhadap rupiah relatif tinggi dengan demikian membuat harga minyak nilam ikut naik. Hal tersebut secara tidak langsung mempengaruhi terhadap ekonomi rumah tangga petani nilam dipedesaan.

Faktor yang lain menunjang tingginya harga minyak nilam adalah karena waktu itu terjadi kelangkaan minyak nilam dipasaran Internasional. Indonesia sebagai salah satu produsen minyak nilam dunia dilanda kemarau panjang sehingga tanaman nilam petani banyak yang mati kekeringan, di Desa Taikako ikut menglami kekeringan namun tidak terlalu dampak pada tanaman yang sudah tumbuh. Walaupun demikian selama tahun 1997-1999 harga minyak nilam mengalami kenaikan yang luar biasa. Harga minyak nilam selalu berubah-ubah sangat tidak menentu., menurut penuturan pedagang yang ada di Kecamatan Sikakap bahwa perubahan harga minyak nilam tergantung pada permintaan eksportir yang ada dikota Padang dan di Medan. Selain itu juga selain itu pedagang yang ada di tingkat kecamatan Sikakap juga ikut melakukan permainan harga supaya petani mau menjual minyak nilamnya sehingga bisa terjadi perubahan dalam waktu satu hari.

Perkembangan nilam dimentawai terdapat 3 (tiga) periode tahapan perkembangan yakni periode pengenalan, periode kejayaan dan periode staknasi. Periode pengenalan merupakan periode uji coba bagi petani yang berada di desa Taikako, untuk mengembangkan tanaman nilam, periode ini terjadi pada tahun 1980an samapi dengan tahun 1997. Pada periode ini tidak banyak petani yang menanam dan membudidayakannya, tanaman nilam dikerjakan hanya sebagai sambilan saja. Periode kejayaan terjadi pada tahun 1997 sampai dengan tahun 2000, disebut periode kejayaan karena pada masa ini hampir semua penduduk mentawai menanam nilam hal ini disbabkan harga minyak nilam dalam $1 \mathrm{~kg}$ mulai meningkat dari Rp. 25.000/kg setiap bulan selalu mengalami kenaikan puncaknya pada tahun 1999 harga minyak nilam melebihi Rp 1 juta/kg. Periode ke tiga adalah masa stakna, pada periode ini dimulai tahun 2001 sampai dilakukannya penelitian dimana petani tidak lagi mengembangkan nilam secara besarbesaran hal ini disebabkan nilam sejak tahun 2001 sampai tahun 2011 berkisar antara Rp 200.000/kg sampai dengan Rp $300.000 / \mathrm{kg}$.

\section{BUDIDAYA DAN PENGELOLAAN TANAMAN NILAM DI DESA TAIKAKO TAHUN 1997-2010}

Masyarakat mentawai pada umumnya 89\% masih sebagai petani tradisional, petani tidak memiliki alat produksi modern seperti mesin pertanian bukan dalam pemeliharaan tanamannya tidak melakukan pemupukan. Topografi desa Taikako meliputi daerah laut, selat, sungai, rawa, dataran rendah samapai dengan pegunungan. Menurut (Rukmana, 2004), dalam bukunya " Prospek Agribisnis dan Teknik Budidaya Nilam" menyatakan bahwa tanaman nilam tumbuh dengan baik pada ketinggian antara 0-400 $\mathrm{m}$ dari permukaan laut, namun pada tanaman nilam yang ditanam pada dataran rendah akan memiliki kandungan minyak yang lebih tinggi dari pada tanaman nilam yang ditanam di daerah dataran tinggi. Dengan demikian sangat sesuai dengan topografi di daerah desa Taikako dimana wilayahnya berada pada ketinggian antara 1-200 m dari permukaan laut, dan petani nilam di Taikako pada umumnya menanam nilamnya pada ketinggian antara 5-20 $\mathrm{m}$ dari permukaan laut.

Penduduk Desa Taikako 98\% kehidupannya masih sangat tergantung pada sektor pertanian, sebagaimana petani umumnya Mentawai setiap keluarga memiliki luasan kebun atau ladang antara 12 hektar untuk setiap keluarga bahkan ada yang mencapai tiga hekatr terutama kebun kelapa, cengkeh, dan kebun sagu. Kebun 
yang mereka miliki ditanami berbagai macam tanaman antara lain kelapa, pisang, keladi, buah-buahan, padi, sagu, cengkeh, ubi, dan berbagai tanaman sayuran lainnya (cabe, kunyit, serai, jahe, dll) untuk memenuhi keperluan rumah tangga seharihari tergantung kondisi tanah. Oleh karenanya, pola berladang masyarakat yang sudah terbiasa dengan tanaman tua dan kondisi lahan yang tidak memungkinkan untuk tanaman muda dengan masa musim kemarau yang panjang juga menjadi faktor pendukung dalam pengembangan perkebunan rakyat (Firdaus, 2012).

Sistem pertanian di Mentawai dikenal dengan sistem bergilir, terutama jenis tanaman mud aseperti pisang, keladi dan lain-lain kecuali sagu, kelapa, cengkeh sudah menjadi kebun permanen. Hal tersebut dilakukan untuk memberi ruang agar tnah bisa subur kembali rotasi tersebut biasanya dilakukan selama 8-12 tahun pada 2-3 lokasi dan apabila ada penambahan luasan kebun maka dibuka kebaun baru kembali. Adapun tahapan pembukaan kebun mentawai adalah sebagai berikut (1) perambahan semak belukat dan kayu-kayu kecil. (2) penanaman tanaman muda seperti pisang, ubi-ubian, keladi dll (3) penumbangan pohon-pohon besar sekaligus melakukan pemotongan dahan-dahan kayu yang sudah ditebang agar jatuh mengenai tanah (4) setelah tiga sampai empat bulan dilakukan pembersihan rumput-rumput dan kayu yang baru tumbuh dan pembersihan dilakukan disetiap saat sampai tanaman bisa menghasilkan. Apabial tanaman tersebut sudah tidak menghasilkan buah lagi 4-6 tahun, maka petani membuka kebun baru lagi dan melakukan hal yang sama setelah 10-12 tahun petani kembali membuka kebun yang pertama dan biasanya tanah sudah lebih subur.

Budidaya tanaman nilam di Desa Taikako dilakukan secara tradisonal pada awalnya tahun 1995 petani hanya menanam di kebun yang sudah ada, yakni disela-sela tanaman pisang dan kelapa. Setelah petani mengetahui terjadinya kenaikan nilam dipasaran maka tanaman nilam yang ditanam sela-sela poson pisang dan kelapa tidak mencukupi, sehingga hampir semua masyarakat Mentawai pada umumnya dan khususnya petani Taikako membuka kebun baru dengan luas rata-rata 1-2 hektar setiap keluarga, bahkan ada yang sampai tiga hektar. Pembukaan kebun baru umumjnya di kerjakan oleh laki-laki di bantu oleh para istri petani, saat penanaman dan pembersihan di kerjakan bersama anak anak.

Menurut (Sudaryani, 2001), dalam buku "Budidaya dan penyulingan nilam", menyatakan bahwa cara yang di tmpuyh dalam pembudidayaan nilam di perlukan langkah-langkah sebagai berikut:
a. Pembibitan
b. Persiapan lahan
c. Penanaman
d. Pemetikan atau panen

Pembibitan tanaman nilam yang dilakukan oleh petani di desa Taikako pada umumnya dengan cara stek yakni menanam potongan cabang atau ranting tanaman induk. Bibit tersebut berupa potonganpotongan ranting sepanjang $\pm 15-25 \mathrm{~cm}$ yang memiliki 3-4 mata tunas daun. Dari satu batang tanaman induk dapat diperoleh 25-65bstek bibit nilam tergantung pada kesuburan dan umur tanaman. Pembibitan tanaman nilam di Desa Taikako umumnya dilakukan dengan dua cara yakni petani menyemaikan bibit terlebih dahulu pada lokasi penyemaian yang telah dibersihkan dahulu dan diberi pelindung, setelah akhirnya tumbuh dan terdapat 2-4 helai daun, baru bibit tersebut dipindahkan kelokasi perkebunan yang telah dipersiapkan sebelumnya. Kedu adengan cara stek bibit yang sudah diperoleh langsung menanam dilokasi perkebunan bila kebun itu merupakan kebun lama maka penananan dilakukan pada sore hari, namun bila kebun itu baru dibuka maka penanaman bisa dilakukan pagi, siang atau sore hari karena pohon-pohon besar sebagai pelindung masih tersedia.

Bibit nilam bagi petani di Desa Taikako diperoleh dari teman-teman sesama petani atau tetangga yang sedang melakukan panen dan biasanya mereka langsung mengambilnya dikebun petani yang sedang melakukan panen, ranting yang keras diambil untuk bibit, sedangkan ranting atas yang lunak dan daun diberikan kepada pemilik kebun. Pada tahun 1995 dimana tanaman nilam belum banyak bibit diperjual belikan dengan harga Rp $5.000 \mathrm{~s} / \mathrm{d} 25.000$ tiap keranjangnya, namun setelah nilam mulai banyak maka petani tidak lagi 
melakukan jual beli bibit tapi cukup membantu petani nilam yang sedang melakukan panen dikebun.

Persiapan lahan penanaman nilam di Desa Taikako pada umumnya dilakukan dengan dua cara yaitu pertama penanaman yang dilakukan disela tanaman pisang, keladi dan disela kebun kelapa, penanaman ditempat tersebut persiapan lahanya lebih cepat karena lahan sudah tersedia tinggal membersihkan gulma yang tidak terlalu banyak. Kedua adalah dengan membuka kebun baru, kegiatan ini lebih membutuhkan waktu kerja yang lebih lama karena tahap pekerjaan yang dilakukan adalah membabat gulma dan kayu-kayu kecil, membuang kayu-kayu yang bisa dilakukan dengan penumbangan memakai parang dan kampak, mencicang/memotong kayu yang telah ditumbang agar pada saat dilakukan penanaman nilam mulai tumbuh antara 5-10 cm maka dilakukan penumbangan kayu-kayu yang cukup besar dengan mempergunakan mesin chian saw.

Penumbangan kayu-kayu besar yang berdiameter $50 \mathrm{~cm}$ keaats oleh petani selalu diupahkan kepada pemilik censo dengan harga antara Rp 5.000 s/d Rp 10.000 setiap pohon yang ditumbang. Setelah kayu-kayu besar ditumbang maka pekerjaan berikut adalah memotong dahan kayu yang ada agar bisa rata mengenai tana $\backslash \mathrm{h}$ sehingga tanaman nilam yanhg sudah mulai tumbu8h tidak tertimbun dan terganggu pertumbuhanya.

Petani nilam di desa Taikako dalam mengerjakan lahan perkebunannya umumnya di kerjakan oleh keluarga petani sendiri yakni, suami istri dan anak-anak sesuai dengan beban kerja yang ada. Namun sebagian ada keluarga yang melakukan persiapan kebun nilamnya secara gotong royong hal ini lebih sering di lakukanh pada loahan kebunh yang baru di buka. Persiapan dan pembukaan kebun untuk penanaman nilam oleh petani di lakukan pada awal musim kemarau yakni pada bulan desember sampai maret sehingga proses pelapukan gulma dan kayu-kayu yang telah di tumbang lebih cepat, dengan demikian pada saat waktu penanaman bibit nilam gulma dan potongan-potongan kayu sudah mulai membusuk.

Tanaman nilam membutuhkan kondisi tanah yang lembab pada masa petumbuhannya, sehingga oleh petani lebih banyak menanam nilam didaerah dataran rendah dan kalaupun ditanam di daerah perbuykitan petani tidak menumbang semua kayu di kebun tersebut, petani selalu menyisahkan pohon-pohon kecil dalm setiap 10-20 meter. Penanaman dilakukan pada awal musim penghujan dan umum nya awal bulan september, namun tidak semua petani memperhitungkan hal tersebut, terutama petani yang lokasi kebun nilamnya memiliki sumber air yang cukup.

Lokasi perkebunan nilam petani di Desa Taikako pada awalnya tidak terlalu jauh dari kampung karena ditanam diselasela tanaman pisang, kelapa atau buahbuahan. Jarak dari kampung ke kebun hanya 500 meter sampai $1 \mathrm{~km}$, namun kebun tersebut hany memiliki luas rata-rata ${ }^{1 / 4}$ hektar. Dengan meningkatnya harga minyak nilam pada tahun 1997 petani merasa luas ${ }^{1 / 4}$ itu tidaklah cukup dengan demikian petani membuka kebun baru yang jaraknya mencapai $2-5 \mathrm{~km}$ dari pemukiman yang ditempuh selama 2-3 jam berjalan kaki. Jalan menuju kebun hanya jalan setapak, sehingga petani harus menyediakan pondok untuk beristarahat, pada saat tertentu petani menginap dikebun baru dan baru pulang pada hari sabtu untuk mengikuti ibadah minggu digereja.

Penanaman bibit nilam dilokasi perkebunan pada umumnya dilakukan di Desa Taikako adalah sebagai berikut : tanah digambarkan dengan menggunakan ujung parang dan ada yang menggunakan cangkul setelah itu langsung menusukan stek bibit nilam dengan kedalaman 2-3 cm didalam tanah dengan batang yang keluar direbahkan sehingga mengenai permukaan tanah, jarak tanam yang dilakukan rata-rata $1 \mathrm{~m} \times 1 \mathrm{~m}$, setelah itu ditanam diberi pelindung dengan menggunakan daun kayu yang ada, umumnya menggunakan daun nibung agar bibit tersebut tidak terkena sinar matahari secara langsung. Setelah melakukan penanaman nilam, perekrjaan petani berikutnya adalah mencari bibit pisnag kemudian ditanam dengan jarak 4 m- $5 \mathrm{~m}$, penanaman pisang bertujuan selain untuk memaksimalkan fungsi lahan yang ada jga diharapkan dapat melindungi tanam nilam agar tanah selalu lembab.

Pemeliharaan tanaman nilam di desa Taikako umumnya dilakukan sepanjang 
waktu dengan kegiatan pencabutan rumput lalu diletakkan di atas ranting kayu agar gulma tersebut cepat mati. Pada hari sabtu laki-laki mencari ikan kesungai ataupun kelaut, sedangkan kaum ibu-ibu mencari kebutuhan dirumah seperti pisang, keladi dan belanja di pasar untuk persiapan pada hari minggu. Selama pemeliharaan tanaman nilam di Desa Taikako sering terkena penyakit daun nilam menjadi kuning dan selama satu minggu tanaman menjadi mati, kedua adalah tumbuhnya cendawan yang berwarna putih pada daun nilam dan alam kelamaan tanaman menjadi mati, untuk membasmi penyakit tanaman tersebut petani mencabut tanaman yang rusak lalu membakarnya dan menanam tanaman baru.

Tanaman nilam di Desa Taikako telah dapat dipanen pada umur 6-7 bulan dan untuk panen berikutnya dilakukan setelah tiga sampai empat bulan setelah panen pertama, hal tersebut tergantung pada kesuburan tanah, pada kebun baru tiga bulan sudah bisa dilakukan panen kembali sedangkan nilam yang ditanam disela-sela tanaman pisang, keladi dan kelapa biasanya setelah umur tujuh bulan baru bisa dilakukan panen pertama dan panen berikutnya setelah empat sampai lima bulan setelah panen perdana. Umur produktif dari tanaman nilam yang ada di Desa Taikako antara dua sampaii tiga tahun tergantung pada keadaan kesuburan tanah. Pada kebun yang baru umur produktif lebih lama dari pada nilam yang ditanam di sela-sela tanaman pisang, keladi dan kelapa.

Proses panen dilakukan dengan cara memotong / menggunting ranting nilam yang dilakukan pada $15-25 \mathrm{~cm}$ dari tanah dengan menggunakan parang atau dengan gunting ranting. Batang nilam dibiarkan tersisa $15-25 \mathrm{~cm}$ agar bisa tumbuh tunas dan cabang baru dengan serentak yang diharapkan dalam waktu tiga bulan yang akan datang sudah bisa dilakukan panen kedua. Dahan dan daun yang sudah dipanen dijemur dan diangin-anginkan selama 2-3 hari dengan beralaskan tikar, plastik, diatas daun kelapa setelah berwarna coklat ke abu-abuan maka petani mencicang dengan ukuran 2-3 cm. Setelah memiliki 3-4 karung yang berat daun mencapai $50-60 \mathrm{~kg}$ baru penyulingan dengan menggunakan sulingan sederhaan yang terbuat dari drum besaloly yang telah dirakit oleh tukang las yang ada di Kecamatan Sikakap.

Alat penyulingan pada tahun 19901996 oleh petani diperoleh dengan memesan pada pedagang yang ada di Kecamatan Sikakap, oleh pedagang memesan sulingan dari Padang. Pada tahun 1997 dengan banyaknya pesanan sulingan dari berbagai kampung diseluruh desa yang ada di Kecamatan Sikakap, Kecamatan Pagai Utara Kecamtan Pagai selatan oleh tukang las yang ada di Sikakap melakukan perakitan sendiri dengan harga satu set pada tahun 1997 sebanyak Rp 750.000 dan sampai dengan tahun 2000 untuk satu set sulingan sudah mencapai Rp 3.000.000.

Proses penyulingan berlangsung selama 6-8 jam, banyaknya kayu bakar yang dipergunakan selama penyulingan 1-1,5 meter kubik, hal tersebut tergantung dari bentuk tungku penyulingan dan jenis kayu bakar yang dipergunakan. Tungku yang tertutup semua panas api tertuju pada drum penyulingan, , sedangkan tungku yang terbuka panas api akan banyak terbuang keluar sehingga waktu penyulingan lebih lama. Jenis kayu bakar yang digunakan dapat mempengaruhi lama waktu dan banyaknya kayu yang dipergunakan. Penggunaan jenis kayu bakar yang lunak proses penyulingan akan membutuhkan waktu yang lebih lama dan jumlah kayu yang dibutuhkan akan lebih banyak, hal ini disebabkan kayu bakar yang igus lunak lebih cepat habis bara apinya dibandingkan dengan kayu api yang keras. Sumber kayu bakar petani diperoleh dari sekitar kebun nilam sendiri.

Petani nilam di Desa Taikako dan pada umumnya diseluruh Kepulauan Mentawai untuk satu kali penyulingan dengan menggunakan sulingan sederhana yang terbuat dari drum bekas oly akan memperoleh sebanyak 08-1,2 kg minyak nila, menurut petani bahwa luas dengan kebun nilam 1 ha yang ditanam dalam satu tahun dapat memperoleh $\pm 65-85 \mathrm{~kg}$ minyak nilam dengan melakukan 60-80 kali penyulingan.

Pada tahun 1990-1996, para petani nilam umumnya menyewa tempat penyulingan kepada orang yang telah memiliki sulingan, umunya para guru yang sekaligus menjadi pedagang di dusun dengan membayar $\mathrm{Rp} 30.000$ sekali 
penyulingan dan pada tahun 1998-2010 sewa sekali penyulingan $\mathrm{Rp}$ 50.000. pada tahun 1996 petani nilam sudah banyak yang memiliki sulingan terutama petani yang meiliki kebun nilam yang luas selain itu sulingan sudah bisa dibeli di Kecamatan Sikakap sehingga hampir seluruh petani nilam memiliki sulingannya sendiri yang dipasang dikebun nilam masing-masing.

Pendapatan petani yang diperoleh dari hasil kebun nilam cukup besar, jika menanam seluas satu ha maka dalam setahun dapat diperoleh minyak nilam sebanyak \pm 70-85 kg bila pada tahun 1995 harganya Rp 25.000, maka dalam setahun petani mendapatkan Rp. 2.500.000,- s/d Rp. 3.000.000 sedangkan pada tahun 19951999 dalam setahun petani akan memperoleh pendapatan sebanyak Rp 80.000.000- Rp 110.000.000,- yang bila dijadikan tiap bulan petani mendapatkan uang sebanyak $\mathrm{Rp} \quad 6.000 .000,-\mathrm{Rp}$ 12.000.000, pada tahun 2000-2010 pendapatan petani nilam dalam 1 ha telah menurun menjadi 29.000.000-32.000.000/ tahun atau setara dengan $\mathrm{Rp} 2.500 .000$ 3.000.000 perbulan.

\section{PEMASARAN DAN PERDAGANGAN MINYAK NILAM DI DESA TAIKAKO}

Pemasaran merupakan rangkaian akhir dari kegiatan petani nilam untuk memperoleh pendapatan/manfaat. Pemasaran petani di Desa Taikako tidak banyak mengalami kesulitan, karena setiap saat pedagang selalu ada yang membeli, hanya harganya yang berbeda-beda tergantung pedagangnya. Pedagang yang ada di dusun dan di desa harganya lebih rendah daripada pedagang yang ada di kecamatan, begitu juga hrga jual pedagang yang ada di kecamatan lebih rendah dari pada harga jual pedagang yang ada di Padang.

Pedagang yang ada di kampung adalah penduduk setempat yang juga petani, sedangkan pedagang yang ada di desa adalah Sinaga yang berasal dari Medan, pedagang di tingkat kecamatan ada beberapa orang diantaranya adalah Jaluhu orang Nias, Simamora dari Medan, dan Usman, Hj Wis yang berasal dari Padang, pedagang yang ada di tingkat kecamatan merupakan pedagang yang sudah besar, mereka membeli minyak nilam sampai ratusan $\mathrm{kg}$ bahkan sampai satu ton. Pedagang di kecamatan menjual minyak nilam yang telah dikumpulkan ke pedagang yang ada di Padang yang dikuasai oleh orang cina mereka sebagai eksportir. Pengiriman minyak nilam dari pedagang di kecamatan ke Padang di tentukan oleh pedagang eksportir yang ada di Padang dan di Medan karena jumlah minya yang banyak sering menggunakan kapal cateran dari Padang.

Perubahan harga minyak di pasaran umumnya ditentukan oleh pedagang ang ada di Padang, yang disampaikan pada setiap minggu kepada pedagang di tingkat kecamatan dan dari pedagang kecamatan menyampaikan ke pedagang tingkat desa dan dusun. Perubahan harga minyak bahkan kadang disampaikan setiap hari tergantung perubahan mata uang dolar.

Petani nilam menjual nilamnya kepada pedagang tergantung dari jumlah nilam yang dimiliki, bila jumlahnya sedikit di bawah $1 \mathrm{~kg}$ biasanya petani menjualnya le pedagang yang ada di dusun atau desa karena tidak terlalu jauh dari tempat petani tidak membutuhkan biaya transportasi, sedangkan bila minyak nilamnya mencapai $1 \mathrm{~kg}-5 \mathrm{~kg}$ umumnya petani menjualnya di pedagang yang ada dikecamatan sedangkan dan bila memiliki minyak nilam mencapai $20 \mathrm{~kg}-100 \mathrm{~kg}$ petani menjualnya ke pedagang yang ada di Padang, tergantung informasi selisih harga yang mereka dapatkan, semakin jauh selisih harga minyak nilam dari pedagang didesa, di kecamatan maupun di Padang maka petani berupaya untuk mengejar harga yang tinggi.

Pemasaran minyak nilam petani dari desa Taikako menuju kecamatan dilakukan dengan menumpang kepada pemilik sampan yang memiliki mesin tempel (sped bod), dengan membayar ongkos pada tahun $1995 \mathrm{Rp} 200$ - Rp 300 per orang sekali berangkat sehingga biaya untuk menuju kecamatan menghabiskan biaya $\mathrm{Rp} 500$, dengan lama waktu tempuh 2 jam, namun karena penumpang waktu harus mengikuti jadwal sipemilik sampan, biasanya berangkat pagi jam 9 pagi dan pulangnya sore jam 16.00 sehingga untuk memasarkan minyak ke kecamatan memerlukan waktu sehari. Pada tahun 1997 - 2000 ongkos penumpang naik menjadi Rp 1.000 per orang atau pulang pergi, dan dari tahun 
2001-2005 ongkos menuju kecamatan mengalami kenaikan menjadi $\mathrm{Rp} 2.500$ per orang sekali jalan dan dari tahun 20062010ongkos menjadi Rp 5000 perorang sehingga untuk memasarkan nilam ke tingkat pedagang yang lebih tinggi akan menghabiskan biaya Rp10.000 ongkos pulang pergi belum termasuk biaya makan karena harus menunggu sipemilik sampan untuk kembali ke kampung.

Melihat dari pola penjualan minyak nilam di Desa Taikako terdapt empat cara tersebut yang paling sering dilakukan oleh petani adalah pada pola ke tiga, sedangkan pola pemasaran yang pertama dan kedua dilakukan apabila dalam kondisi petani mendesak untuk keperluan sehari-hari seperti membeli rokok, gula, minyak tanah, dan yang sifatnya kebutuhan mendadak, jumlah minyak nilam yang diperjual belikan pada pola pemsaran pertama dan kedua hanya seidkit 1 ons - 5 ons sedangkan cara pemasaran ketiga umumnya dilakukan petani apabila memiliki minyak nilam antara $1 \mathrm{~kg}$ - $10 \mathrm{~kg}$. Untuk pola pemasaran ke empat dilakukan petani yang telah memiliki minyak nilam lebih dari jeregen atau antara $10 \mathrm{~kg}$ ke atas, umumnya dilakukan oleh petani yang memiliki kebun bilam yang luas serta pedagang pengumpul di dusun dan di desa. Pola pemasaran minyak nilam di Desa Taikako sejak tahun 1995 sampai dengan tahun 2010 adalah sebagai berikut

\section{Pola 1.}

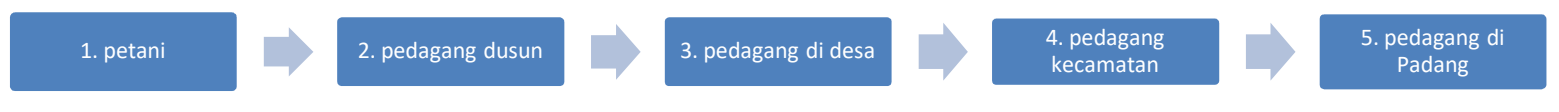

\section{Pola 2.}

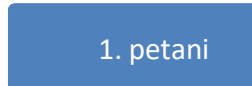

$$
\text { 1. petani }
$$
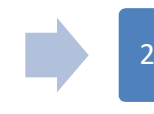

2. pedagang di desa

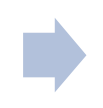

3. pedagang di Kecamatan

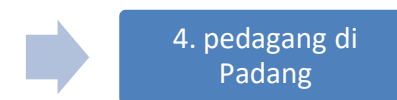

Pola 3.

1. petani
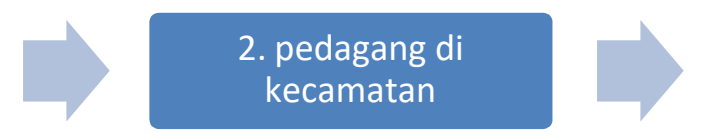

3. pedagang di Padang

\section{Pola 4.}

\section{1. petani}

Semakin panjang rantai niaga pemasaran minyak nilam maka semakin murah harga yang diperoleh oleh petani karena harus dipotong dengan keuntungan para pedagang, sebaliknya semakin pendek tataniaga pemasaran semakin besar harga yang diperoleh petani. Pada tahun 1995 pada saat harga minyak nilam masih rendah oleh petani lebih banyak menyimpan minyak nilam untuk dikumpulkan, bila sudah mencapai satu jeregn sekitar $5 \mathrm{~kg}$ baru petani menjualnya di pusat kecamatan, karena pada saat itu pembeli di tingkat dusun dan desa belum ada. Setelah tahun

\section{2. pedagang di Padang}

1997 terjadinya kenaikan harga minyak nilam, petani nilam bertambah sehingga jumlah minyak nilam yang beredar di kampung dan di desa bertambah banyak sehingga pedagang bermunculan sampai didusun-dusun.

Pada tahun 1997 oleh pedagang di desa Taikako dan di beberapa tempat lainnya mengalami kerugian yang cukup besar, karena adanya petani nilam yang mencampur minyak nilam dengan kayu, saat pedagang pengumpul di tingkat dusun dan desa menjualnya kepedagang yang lebih besar di kecamatan yang pada 
umumnya pedagang besar memiliki alat untuk menguji kemurnian minyak nilam, baru diketahui bahwa nilam telah dicampur dengan bahan minyak lain sehingga hampir selama 1997 pedagang ditingkat dusun dan desa tidak berani mengambil minyak nilam dari petani, akibat dari itu juga terjadi kerusakan harga yang cukup tajam dari harga 350.000 menjadi 100.000 dan pedagang di tingkat kecamatanpun sudah sangat berhati-hati untuk membeli minyak nilam, saat itu sempat ada ancaman dari pedagang untuk tidak mau membeli nilam masyarakat lagi. Mendengar ancaman dari pedagang seperti itu pemerintahan desa dan dusun menyampaikan kepada seluruh warganya agar siapa yang kedapatan memalsukan minyak nilam maka dia akan dilaporkan langsung ke pihak kepolisian dan tidak diperbolehkan menanam nilam dilingkungan desa Taikako. Perintah dari pemerintahan desa Taikako dilakukan juga oleh desa-desa lainnya, sehingga pada tahun 1998 petani nilam sudah sangat menjaga kwalitas minyaknya sampai di tangan dipedagang.

Produksi minyak nilam di desa Taikako puncaknya terjadi pada tahun 1999 sampai tahun 2000, baik dar segi luas kebun yang dikelola oleh petani maupun jumlah minyak yang diperolehnya sesuai dengan tabel diatas dapat dilihat bahwa luas lahan nilam mencapai 165 ha dengan produksi mencapai lebih dari 12 tiap tahunnya hanya dari desa Taikako. Pada tahun 2001 sampai dengan tahun 2005 walau terjadi penurunan namun tidak terlalu drastis hal ini disebabkan nilam masih menjadi produk unggulan sumber ekonomi bagi petani, pada tahun 2006-2010 jumlah petani, luas lahan kebun nilam maupun produksi minyak nilam di desa Taikako mulai menurun hal ini disebabkan selain harganya yang tidak lagi mengalami kenaikan, petani mendapatkan pertanian coklat sebagai produk unggulan baru.

\section{KESIMPULAN}

Budidaya nilam telah membuat dinamika bagai kehidupan sosial ekonomi masyarakat desa Taikako. Dinamika tersebut adalah meningkatnya pendapatan petani nilam dari $\mathrm{Rp} 100.000$ tiap minggunya menjadi $\mathrm{Rp}$ 350.000-Rp500.000. Meningkatnya pendapatan petani nilam telah merubah pola pembangunan rumah penduduk yang seluruhnya dari kayu menjadi rumah semi permananen dan permananen. Dengan meningkatnya pendapatan petani nilam maka dari tahun ke tahun tingkat pendidikan penduduk desa Taikako semakin meningkat.

\section{DAFTAR PUSTAKA}

Firdaus, F. (2012). Puar Cama Untuk Anak Cucu: Kearifan Lokal Untuk Sustainability Forest di Manggarai Barat. Jurnal Ilmu Sosial Mamangan, 1(1), 39-50.

Rukmana, R. (2004). Prospek Agribisnis dan Teknik Budidaya Nilam. Yogyakarta: Kanisius.

Sudaryani, T. (2001). Budidaya dan Penyulingan Nilam. Jakarta: Penebar Swadaya.

Surya, A. (1991). Alasan-alasan Yang Mempengaruhi Petani Nilam Tanjung Kuning Berlandang Nilam di Durian Gadang Kinali Pasaman. Universitas Andalas, Padang.

Triyani. (2004). Petani Nilam di Desa VI Koto Selatan, Kecamatan Kinali Kabupaten Pasaman Barat. Universitas Andalas, Padang.

Wati, M. (2004). Sejarah Petani Nilam di Nagari Kinali Kabupaten Pasaman Periode 1996-2002. Sekolah Tinggi Keguruan dan Ilmu Pendidikan (STKIP) PGRI Sumatera Barat, Padang. 
